\title{
ZARZUT NADUŻYCIA PRAWA PODMIOTOWEGO A POZBAWIENIE PRAWA DO ZACHOWKU. GLOSA DO WYROKU SĄDU NAJWYŻSZEGO Z DNIA 28 MARCA 2018 ROKU, V CSK 428/17
}

\begin{abstract}
Abstrakt: Glosowany wyrok dotyczy niezwykle istotnej kwestii dopuszczalności stosowania art. 5 k.c. do roszczeń o zachowek zarówno w zakresie miarkowania jego wysokości, jak również pozbawienia uprawnionego w całości zachowku. Pomimo że samo rozstrzygnięcie Sądu Najwyższego na tle stanu faktycznego sprawy zasługuje na aprobatę, uwagi krytyczne wzbudza teza wyroku, zgodnie z którą nie jest dopuszczalne oddalenie powództwa o zachowek na podstawie art. 5 k.c.
\end{abstract}

Słowa kluczowe: nadużycie prawa podmiotowego, zachowek, wydziedziczenie

Stanowisko wyrażone w treści uzasadnienia glosowanego wyroku Sądu Najwyższego z dnia 28 marca 2018 roku $^{1}$ stanowi podłoże do zabrania po raz kolejny głosu w toczącej się już dyskusji o dopuszczalności stosowania art. 5 kodeksu cywilnego do roszczeń z tytułu zachowku. Omawiane orzeczenie jest o tyle interesujące, że stanowi wyraźne odejście od — wydawać by się mogło — utrwalonej już w tym zakresie linii orzeczniczej Sądu Najwyższego, dopuszczającej pozbawienie osoby uprawnionej prawa do zachowku na mocy art. 5 k.c. w sytuacjach wyjątkowych $^{2}$. Mianowicie, zgodnie z tezą glosowanego wyroku, nie jest dopuszczalne oddalenie powództwa o zachowek na podstawie art. 5 k.c.

1 V CSK 428/17, OSNC zbiór dodatkowy 2019/A/14.

2 Por. między innymi wyrok Sądu Najwyższego z dnia 14 marca 2018 roku, II CSK 276/17, Legalis nr 1835926; wyrok Sądu Najwyższego z dnia 28 marca 2018 roku, IV CNP 10/17, Legalis 1814369; postanowienie Sądu Najwyższego z dnia 11 lipca 2012 roku, I CSK 75/12, Legalis nr 736908; postanowienie Sądu Najwyższego z dnia 19 grudnia 2019 roku, I CSK 271/19, Legalis 2277350, a także wyrok Sądu Apelacyjnego w Białymstoku z dnia 30 maja 2018 roku, I ACa 125/18, Legalis nr 180487 oraz wyrok Sądu Apelacyjnego w Łodzi z dnia 11 października 2018 roku, I ACa 262/18, Legalis nr 1857677. 
Niniejsza glosa ma charakter krytyczny w zakresie przyjętej przez Sąd Najwyższy tezy o niedopuszczalności stosowania art. 5 k.c. co do roszczeń o zachowek, aprobujący zaś w zakresie rozstrzygnięcia merytorycznego, jakie zapadło na tle danego stanu faktycznego.

W okolicznościach sprawy będących podstawą wydanego rozstrzygnięcia pozwany nabył na mocy testamentu notarialnego spadek po zmarłym spadkodawcy. W testamencie tym spadkodawca wydziedziczył jednocześnie swoich spadkobierców ustawowych - córkę i jej synów. Jako przyczynę wydziedziczenia wskazał uporczywe niedopełnianie względem niego obowiązków rodzinnych, brak zainteresowania jego stanem zdrowia, a także postępowanie w sposób sprzeczny z zasadami współżycia społecznego. Stan ten utrzymywać się miał przez kilka lat poprzedzających sporządzenie testamentu. W tym okresie spadkodawca nie widywał ani córki, ani wnuków, co skutkowało ustaniem więzi właściwych dla relacji ojca $\mathrm{z}$ córką oraz dziadka $\mathrm{z}$ wnukami. $\mathrm{Z}$ uwagi na brak pomocy z ich strony, spadkodawca utracił do nich zaufanie i nie mógł wybaczyć takiego zachowania. Sąd ustalił również, że na chwilę wydziedziczenia wnuków przez spadkobiercę, jeden z nich miał 16 lat, drugi zaś, choć miał 19 lat, był ubezwłasnowolniony i całkowicie niezdolny do pracy. W związku z tym nie mieli oni możliwości samodzielnych odwiedzin dziadka. Ponadto zerwanie kontaktów rodzinnych z córką i wnukami nastąpiło z inicjatywy samego spadkodawcy, co wynikało z jego pretensji do córki o składanie niekorzystnych dla niego zeznań w trakcie postępowania rozwodowego z babcią, które to pretensje przeniesione zostały również na wnuków.

Wydziedziczeni wnukowie wnieśli przeciwko spadkobiercy testamentowemu powództwo o zasądzenie kwoty pieniężnej tytułem należnego zachowku. Sąd pierwszej instancji - uznając, że w sprawie brak było podstaw do wydziedziczenia — zasądził na ich rzecz należną kwotę tytułem zachowku. Zdaniem sądu brak było uzasadnionych przesłanek do obciążenia powodów zaistniałym pogorszeniem relacji rodzinnych. Wynikało to nie tylko $\mathrm{z}$ ich młodego wieku, ale również faktu, że jeden z nich był upośledzony psychicznie. Powodowie z tych przyczyn nie mogli samodzielnie podejmować decyzji, planować i odbywać wyjazdów do dziadka.

Sąd drugiej instancji oddalił apelację pozwanego, w pełni podzielając rozstrzygnięcie Sądu pierwszej instancji. Pozwany od wyroku sądu drugiej instancji złożył skargę kasacyjną, podnosząc w ramach zarzutów skargi naruszenie prawa materialnego - to jest art. 1008 pkt 3 k.c. poprzez błędne przyjęcie, że zachowanie powodów nie wypełniało przesłanki określonej w tym przepisie, a także naruszenie art. 5 k.c. poprzez uznanie, że brak było podstaw do przyjęcia, iż zgłoszone przez powodów żądanie jest sprzeczne z zasadami współżycia społecznego i stanowi nadużycie prawa.

Ostatecznie Sąd Najwyższy oddalił wniesioną skargę kasacyjną.

Odnosząc się do zarzutu naruszenia przez sąd drugiej instancji art. 1008 pkt 3 k.c., Sąd Najwyższy wskazał, że w świetle ustaleń stanu faktycznego, pozostających poza kontrolą sądu kasacyjnego, nie istniały rzeczywiste okoliczności mogą- 
ce przemawiać za skutecznym wydziedziczeniem powodów przez spadkodawcę. Sąd Najwyższy podkreślił, że utrzymywanie poprawnych relacji rodzinnych wymaga zaangażowania obu stron, zwłaszcza osób starszych w odniesieniu do dzieci. $\mathrm{Z}$ uwagi na postawę spadkodawcy wobec córki i wnuków nie mógł on oczekiwać, że wnuki będą utrzymywać kontakty z dziadkiem, zwłaszcza, że zerwanie relacji nastąpiło w okresie ich małoletności (jeden z wnuków miał jedenaście lat, a drugi, dotknięty autyzmem - czternaście). Rozstrzygnięcie Sądu Najwyższego w zakresie przyjęcia, że w sprawie nie zachodzą przesłanki uzasadniające wydziedziczenie uprawnionych do zachowku niewątpliwie należy ocenić jako trafne. Sąd Najwyższy wskazał przy tym, że to sam spadkodawca był osobą chłodną emocjonalnie $\mathrm{w}$ stosunku do swoich wnuków, nie był zaangażowany w pielęgnowanie relacji z nimi, utrzymywał sporadyczne kontakty, a relację z matką powodów zerwał niemal zupełnie. Spadkodawca zabronił również informowania rodziny córki o stanie swojego zdrowia. Spadkodawca nie mógł zatem oczekiwać serdeczności od wnuków, chęci utrzymywania kontaktów, odwiedzania go, pomocy i wsparcia, jeśli jego zachowanie było przyczyną zerwania kontaktów rodzinnych również $\mathrm{z}$ powodami.

W konsekwencji, z uwagi na bezskuteczność wydziedziczenia, wnukowie uprawnieni byli do dochodzenia roszczeń z tytułu zachowku od spadkobiercy testamentowego. Sąd Najwyższy, odnosząc się do zarzutu naruszenia art. 5 k.c., w pierwszej kolejności zwrócił uwagę na istotę zarzutu nadużycia prawa podmiotowego, uznając, że zastosowanie art. 5 k.c. nie może prowadzić do modyfikacji normy prawnej, ani do nabycia prawa lub jego zniweczenia. Uwzględnienie zarzutu nadużycia prawa podmiotowego polega bowiem na tym, że z uwagi na konkretne okoliczności faktyczne, wykreowane normą prawną prawo podmiotowe - zwykle jedynie czasowo - nie podlega ochronie. Sąd Najwyższy podkreślił, że wyjątkowy charakter przepisu art. 5 k.c. pociąga za sobą konieczność ścisłej jego wykładni, a także ostrożnego stosowania w wyjątkowych wypadkach. Ponadto $\mathrm{z}$ reguły stosowanie art. 5 k.c. nie może skutkować trwałą utratą prawa podmiotowego.

Głównym argumentem przemawiającym zdaniem Sądu Najwyższego za niedopuszczalnością stosowania art. 5 k.c. do roszczeń o zachowek jest zawarcie przez ustawodawcę w art. 928 oraz 1008 k.c. zamkniętego katalogu przypadków niegodności dziedziczenia oraz wydziedziczenia, których zastosowanie skutkuje pozbawieniem uprawnionego prawa do zachowku. Są to wyłączne podstawy ograniczenia zasady ochrony dziedziczenia wyrażonej w art. 21 ust. 1 Konstytucji RP. W związku z tym katalog przypadków określonych w art. 928 oraz 1008 k.c. nie podlega rozszerzeniu, zwłaszcza że art. 5 k.c. odwołuje się do nieokreślonych pojęć w postaci społeczno-gospodarczego przeznaczenia prawa oraz zasad współżycia społecznego. Sąd Najwyższy nie podzielił poglądu wyrażonego w niepublikowanym wyroku z dnia 25 stycznia 2001 roku (V CNP 250/00), według którego dopuszczalne jest w sytuacjach wyjątkowych pozbawienie zachowku na 
podstawie art. 5 k.c. Ponadto krytycznie odniósł się do możliwości obniżenia zachowku w oparciu o art. 5 k.c., za którym to poglądem opowiedział się Sąd Najwyższy w uchwale z dnia 19 maja 1981 roku (III CZP 18/81), oraz do wyroków z dnia 7 kwietnia 2004 roku (IV CK 215/03, niepubl.) oraz z dnia 16 czerwca 2016 roku (V CSK 625/15). Sąd Najwyższy w glosowanym wyroku wskazał bowiem, że ewentualne nadużycie prawa podmiotowego należałoby oceniać w relacji pomiędzy uprawnionym do zachowku a zobowiązanym spadkobiercą.

Rozstrzygnięcie Sądu Najwyższego oddalające skargę kasacyjną pozwanego należy uznać za trafne. Wydziedziczenie wnuków spadkodawcy w okolicznościach sprawy nie było skuteczne, ponieważ nie zachodziła jedna z koniecznych przesłanek pozbawienia uprawnionego prawa do zachowku. Istotne $\mathrm{z}$ punktu widzenia skuteczności zastosowania art. 1008 pkt 3 k.c. jest to, by uporczywe niedopełnianie obowiązków rodzinnych względem spadkodawcy polegało na obiektywnie nagannym zachowaniu uprawnionego do zachowku, objawiającym się poprzez wielokrotne lub długotrwałe zaniedbywanie uzasadnionych potrzeb spadkodawcy w sferze materialnej i emocjonalnej lub na działaniu względem niego w sposób sprzeczny z zasadami współżycia społecznego ${ }^{3}$. Ocena takiego zachowania winna również uwzględniać stosunki panujące w konkretnej rodzinie, stanowiące konsekwencję zdarzeń niezależnych od spadkodawcy, spadkobiercy czy uprawnionego do zachowku ${ }^{4}$. W analizowanej sprawie nie można było stwierdzić, że zachowania powodów spełniały przesłanki do skutecznego wydziedziczenia ich przez spadkodawcę, mając jednocześnie na uwadze ich wiek i stan umysłu.

Pomimo zaaprobowania samego rozstrzygnięcia Sądu Najwyższego, należy zgłosić uwagi krytyczne dotyczące poglądu wyrażonego w glosowanym wyroku o niedopuszczalności stosowania art. 5 k.c. do oceny roszczeń o zachowek.

Odnosząc się do powyższego, należy zauważyć, że przepis art. 5 k.c. ma zastosowanie do oceny wszelkich stosunków prawnych, o ile brak jest w tym zakresie przepisu szczególnego odwołującego się wprost do zasad współżycia społecznego lub do innych okoliczności, regulując jednocześnie skutki ich naruszenia ${ }^{5}$. Takim przepisem szczególnym jest przykładowo art. $144^{1}$ k.r.o. dotyczący oceny żądania alimentów pod kątem jego zgodności z zasadami współżycia społecznego. $\mathrm{Z}$ uwagi na to, że przepis art. 5 k.c. jest przepisem prawa materialnego, sąd jest każdorazowo zobligowany do zbadania, czy zachodzą przesłanki do jego zastosowania $\mathrm{z}$ urzędu ${ }^{6}$. W doktrynie powszechnie przyjmuje się, że art. 5 k.c. ma zasto-

3 Postanowienie Sądu Najwyższego z dnia 25 stycznia 2018 roku, I CSK 545/17, Legalis nr 2275101; wyrok Sądu Apelacyjnego w Białymstoku z dnia 12 czerwca 2019 roku, I ACa 211/19, Legalis 2238499.

4 Postanowienie Sądu Najwyższego z dnia 25 stycznia 2018 roku, Legalis nr 2275101.

5 Wyrok Sądu Najwyższego z dnia 16 czerwca 2016 roku, V CSK 625/15, OSNC $2017 \mathrm{nr} 4$, poz. 45 , s. 67.

6 Postanowienie Sądu Najwyższego z dnia 29 maja 2020 roku, I CSK 625/19, Legalis nr 239369. 
sowanie także do spadkowych praw podmiotowych ${ }^{7}, \mathrm{z}$ czym niewątpliwie należy się zgodzić. Przyjęcie powyższej tezy implikuje zatem potrzebę określenia relacji, jaka zachodzi między art. 5 a 928 k.c. oraz art. 1008 k.c. W tym zakresie należy zauważyć, że przepis art. 928 k.c. jest przepisem szczególnym wobec art. $922 \S 1$ k.c., który wyraża podstawową regułę, że prawa i obowiązki majątkowe zmarłego przechodzą z chwilą jego śmierci na jedną lub kilka osób stosownie do przepisów księgi czwartej k.c. Natomiast przepis art. 1008 k.c. jest przepisem szczególnym w stosunku do art. $991 \S 1$ k.c., według którego zstępnym, małżonkowi oraz rodzicom spadkodawcy, którzy byliby powołani do spadku z ustawy należy się zachowek z reguły w wysokości połowy udziału spadkowego, który by przypadał przy dziedziczeniu ustawowym. Przepisy art. 928 k.c. i 1008 k.c., określające w sposób enumeratywny przypadki uznania spadkobiercy za niegodnego dziedziczenia bądź wydziedziczenia go przez spadkodawcę, modyfikują ogólne reguły spadkobrania poprzez wykluczenie określonych osób z kręgu podmiotów uprawnionych do spadku bądź jego części. Zatem z uwagi na swój charakter, przepisy art. 928 k.c. oraz — istotny z punktu widzenia rozstrzygnięcia Sądu Najwyższego — art. 1008 k.c. nie mogą stanowić przepisów szczególnych wobec art. 5 k.c. W sytuacji skutecznego wydziedziczenia uprawnionego do zachowku, do oceny jego zachowania nie ma zastosowania art. 5 k.c., ponieważ skutkiem tego wydziedziczenia jest właśnie pozbawienie prawa do zachowku. W tym przypadku zastosowanie art. 5 k.c. byłoby zatem bezprzedmiotowe.

Należy następnie zauważyć, że kwestią sporną wśród zwolenników stosowania przepisu art. 5 k.c. do zachowku jest to, czy przepis ten może stanowić podstawę wyłącznie do miarkowania wysokości zachowku, czy też oddalenia w całości powództwa o zachowek. Zgodnie z poglądem, który przeważa dziś w doktrynie i orzecznictwie sądowym, przepis ten może stanowić podstawę zarówno do zmniejszenia zachowku, jak i pozbawienia go w całości ${ }^{8}$. Natomiast

7 Wyrok Sądu Najwyższego z dnia 7 kwietnia 2004 roku, IV CK 215/03, Legalis nr 73074; wyrok Sądu Najwyższego z dnia 14 marca 2018 roku, II CSK 276/17, Legalis nr 1835926; postanowienie Sądu Najwyższego z dnia 19 grudnia 2019 roku, I CSK 271/19, Legalis nr 2277350; S. Wójcik, F. Zoll, [w:] System Prawa Prywatnego. Prawo spadkowe, t. 10, Warszawa 2015, s. 1100; E. Skowrońska-Bocian, J. Wierciński, [w:] Kodeks cywilny. Komentarz, t. 6. Spadki, red. J. Gudowski, Warszawa 2017, komentarz do art. 991 k.c., pkt 19; M. Królikowski, Mechanizm sadowego miarkowania wysokości zachowku jako przejaw dynamicznej wykładni prawa cywilnego, „Przegląd Prawa i Administracji” 120, 2020, cz. 1, s. 407.

8 Wyrok Sądu Najwyższego z dnia 14 marca 2018 roku, II CSK 276/17, Legalis nr 1835926; wyrok Sądu Najwyższego z dnia 28 marca 2018 roku IV CNP 10/17, Legalis nr 1814369; postanowienie Sądu Najwyższego z dnia 11 lipca 2012 roku, I CSK 75/12, Legalis nr 736908; wyrok Sądu Apelacyjnego w Katowicach z dnia 15 maja 2018 roku, I ACa 1139/17, Legalis nr 1808267; wyrok Sądu Apelacyjnego w Warszawie z dnia 26 lutego 2019 roku, V ACa 1604/17, Legalis nr 2122972; wyrok Sądu Okręgowego w Olsztynie z dnia 13 czerwca 2019 roku, IX Ca 1555/18, Legalis nr 1983582; P. Księżak, [w:] Kodeks cywilny. Komentarz, red. K. Osajda, Warszawa 2020, komentarz do art. 991 k.c., pkt 48; K. Kuźmicka-Sulikowska, [w:] Kodeks cywilny. Komentarz, red. E. Gniewek, P. Machnikowski, Warszawa 2019, komentarz do art. 991 k.c., pkt 7; T. Sokołowski, 
według poglądów mniejszościowych, zastosowanie przepisu art. 5 k.c. ograniczone jest wyłącznie do obniżenia zachowku ${ }^{9}$ bądź też do oddalenia w całości powództwa o zachowek ${ }^{10}$.

Odnosząc się do powyższej kwestii, należy przychylić się do poglądu większościowego. Przemawia za tym zwłaszcza istota klauzul generalnych przejawiająca się w ich funkcji indywidualizacyjnej oraz słusznościowej. Przepis art. 5 k.c. ma na celu realizację postulatu indywidualizacji w zakresie stosowania prawa w kierunku pozbawienia ochrony roszczeń o zachowek, których dochodzenie jest ocenione negatywnie pod kątem panujących w społeczeństwie norm i ocen moralnych. Oznacza to, że konstrukcja nadużycia prawa podmiotowego może i powinna mieć zastosowanie także do oceny roszczenia o zapłatę zachowku. Chodzi zatem o dostosowanie norm prawnych do konkretnych, często nietypowych stanów faktycznych, przy jednoczesnym wydaniu przez organ stosujący prawo rozstrzygnięcia słusznego, a zatem sprawiedliwego ${ }^{11}$. Istotne znaczenie na gruncie regulacji prawnospadkowych ma realizacja powyższych funkcji urzeczywistniających obowiązki moralne ${ }^{12}$, których źródłem są szczególnego rodzaje więzi społeczne, a mianowicie więzi rodzinne - $\mathrm{i}$ to te najbliższe. Obowiązki te wynikają zatem z solidarności rodzinnej stanowiącej w dalszym ciągu moralną wartość, pomimo tego, że struktura rodziny i jej funkcje ulegają przemianom zwłaszcza w kierunku postępujących procesów indywidualizacji i wzrostu autonomii jednostek ${ }^{13}$. Należy zatem przyjąć, że zasady współżycia społecznego rozumiane jako normy moralne zawierające reguły postępowania w stosunkach między ludźmi, odwołujące się do powszechnie akceptowanych w społeczeństwie wartości moralnych ${ }^{14}$, odgrywają szczególne znaczenie na gruncie instytucji prawnej zachowku. Zasadności przyjętego poglądu nie podważa również reguła, że zastosowanie art. 5 k.c.

[w:] Kodeks cywilny, t. 3. Komentarz do art. 627-1088, red. M. Gutowski, Warszawa 2019, komentarz do art. 991 k.c., nb 3.

9 Uchwała Sądu Najwyższego z dnia 19 maja 1981 roku, III CZP 18/81, OSNCP 1981 nr 12, poz. 228; wyrok Sądu Najwyższego z dnia 16 czerwca 2016 roku, V CSK 625/15, OSNC 2017 nr 4, poz. 45 , s. 67.

${ }_{10}$ M. Załucki, [w:] Kodeks cywilny. Komentarz, t. 6. Spadki (art. 922-1087), red. M. Fras, M. Habdas, Warszawa 2019, komentarz do art. 991 k.c., pkt 22. Zdaniem autora obowiązujące przepisy umożliwiają jedynie oddalenie w całości żądania uprawnionego ocenionego w świetle art. 5 k.c. Brak jest przy tym podstawy prawnej do miarkowania zachowku, którego wysokość precyzyjnie określa przepis art. $991 \S 1$ k.c.

11 M. Wilejczyk, Zagadnienia etyczne części ogólnej prawa cywilnego, Warszawa 2014, s. 66.

12 Wyrok Sądu Najwyższego z dnia 14 marca 2018 roku, II CSK 276/17, Legalis nr 1835926; postanowienie Sądu Najwyższego z dnia 19 grudnia 2019 roku, I CSK 271/19, Legalis nr 2277350; postanowienie Sądu Najwyższego z dnia 11 lipca 2012 roku, I CSK 75/12, Legalis nr 736908; wyrok Sądu Najwyższego z dnia 7 kwietnia 2004 roku, IV CK 215/03, Legalis nr 73074.

13 Zob. szerzej o socjologicznym ujęciu solidarności rodzinnej A. Kwak, Rodzina na wiele wariantów, ale czy z mniejszym zakresem solidarności?, „Studia Socjologiczne” 2017, nr 2, s. 145-166.

14 Z. Ziembiński, Wstęp do aksjologii dla prawników, Warszawa 1980, s. 230. 
nie może skutkować trwałym pozbawieniem uprawnionego przysługującego mu prawa podmiotowego. Reguła ta nie ma bowiem charakteru absolutnego, o czym świadczą również rozstrzygnięcia sądów dotyczące roszczeń z naruszeń zasad konkurencji, przedawnienia czy dóbr osobistych ${ }^{15}$.

Warto również zwrócić uwagę na nietrafną uwagę Sądu Najwyższego, że w glosowanym wyroku przemawia przeciwko stosowaniu art. 5 k.c. do roszczeń o zachowek również to, iż odwołuje się on do niedookreślonych pojęć w postaci społeczno-gospodarczego przeznaczenia prawa oraz zasad współżycia społecznego. W tej mierze należy zauważyć, że wśród przesłanek wydziedziczenia (art. 1008 k.c.) znajdują się zwroty niedookreślone, w tym klauzula generalna zasad współżycia społecznego. Mianowicie pierwszą przesłanką wydziedziczenia jest uporczywe postępowanie wbrew woli spadkodawcy w sposób sprzeczny z zasadami współżycia społecznego, która de facto pochłania zakresowo kolejną przesłankę wydziedziczenia $\mathrm{w}$ postaci uporczywego niedopełniania względem spadkodawcy obowiązków rodzinnych (art. 1008 pkt 1 i 3 k.c.). Stąd też cecha niedookreśloności, która jest immanentną cechą klauzul generalnych, nie powinna stanowić argumentu przeciwko stosowaniu konstrukcji nadużycia prawa podmiotowego do roszczeń o zachowek.

Niewątpliwie Sąd Najwyższy ma rację, podkreślając, że przepis art. 5 k.c. należy stosować ostrożnie $\mathrm{w}$ wyjątkowych wypadkach. Wynika to $\mathrm{z}$ charakteru tego przepisu, który przełamuje zasadę, że wszystkie prawa podmiotowe korzystają z ochrony prawnej. Stąd też zmniejszenie zachowku, a zwłaszcza jego pozbawienie, powinno nastąpić wyłącznie w sytuacjach wyjątkowych ${ }^{16}$. Przez sytuacje wyjątkowe należy przy tym rozumieć przypadki rażącego nadużycia prawa, obejmujące w szczególności skrajnie naganne pod kątem etycznym zachowanie uprawnionego do zachowku.

W ramach problematyki stosowania art. 5 k.c. do roszczeń o zachowek należy zwrócić uwagę jeszcze na dwie kwestie. Po pierwsze - przyczyną obniżenia lub pozbawienia prawa do zachowku może być zarówno naganne pod względem etycznym zachowanie uprawnionego do zachowku, jak również okoliczności natury obiektywnej, niezwiązane z ujemną oceną etyczną zachowania człowieka ${ }^{17}$. Po drugie - ocena z punktu widzenia art. 5 k.c. może obejmować nie tylko stosunek uprawnionego do zachowku ze spadkodawcą, ale również stosunek upraw-

15 Zob. na przykład wyrok Sądu Najwyższego z dnia 16 czerwca 2016 roku, V CSK 625/15, OSNC 2017 nr 4, poz. 45, s. 67; J. Kuźmicka-Sulikowska, [w:] Kodeks cywilny. Komentarz, red. E. Gniewek, P. Machnikowski, Warszawa 2019, komentarz do art. 991 k.c., pkt 7.

16 Wyrok Sądu Najwyższego z dnia 25 stycznia 2001 roku, IV CKN 250/00, Legalis nr 277974; uchwała Sądu Najwyższego z dnia 19 maja 1981 roku, III CZP 18/81, OSNCP 1981 nr 12, poz. 228; postanowienie Sądu Najwyższego z dnia 11 lipca 2012 roku, I CSK 75/12, Legalis nr 736908; wyrok Sądu Najwyższego z dnia 14 marca 2018 roku, II CSK 276/17, Legalis nr 1835926.

17 Wyrok Sądu Najwyższego z dnia 16 czerwca 2016 roku, V CSK 625/15, OSNC $2017 \mathrm{nr} 4$, poz. 45 , s. 67. 
nionego do zachowku z zobowiązanym do jego zapłaty ${ }^{18}$. Oznacza to, że zakres stosowania art. 5 k.c. jest szerszy niż katalog przesłanek wydziedziczenia oraz niegodności dziedziczenia, bowiem obejmuje przypadki nieobjęte dyspozycją art. 928 oraz 1008 k.c. ${ }^{19}$. W ramach relacji zachodzącej między uprawnionym do zachowku a zobowiązanym do jego zapłaty okolicznością uzasadniającą modyfikację jego wysokości - która jednocześnie ma charakter obiektywny, niezwiązany z nagannością zachowania - może być przykładowo szczególnie trudna sytuacja majątkowa zobowiązanego ${ }^{20}$. Należy przy tym zgodzić się z poglądem, że całkowite pozbawienie uprawnionego zachowku na podstawie art. 5 k.c. powinno ograniczać się do normatywnie wskazanych przesłanek wydziedziczenia ${ }^{21}$.

Dokonując oceny roszczenia o zachowek pod kątem art. 5 k.c. w przypadku sytuacji odnoszących się do nagannego pod kątem etycznym zachowania uprawnionego do zachowku wobec spadkodawcy, należy mieć na uwadze, że koniecznym jest ustalenie, czy spadkodawca nie dokonał w testamencie wydziedziczenia z uwagi na przeszkody natury prawnej lub faktycznej. Pierwsza ze wskazanych przeszkód dotyczy braku pełnej zdolności do czynności prawnych, co uniemożliwia dokonanie jakichkolwiek rozrządzeń testamentowych (art. $944 \S 1$ k.c.). Druga kategoria przeszkód może dotyczyć niepełnosprawności lub wieku ograniczających możliwości poznawcze, niesamodzielności w codziennym funkcjonowaniu i uzależnieniu od pomocy innych osób, uniemożliwiających sporządzenie testamentu pomimo posiadania pełnej zdolności do czynności prawnej, a także brak świadomości prawnej. Przyczyną natury faktycznej jest również okoliczność, w której spadkodawca nie zdążył wydziedziczyć uprawnionego do zachowku ${ }^{22}$ po

18 Postanowienie Sądu Najwyższego z dnia 19 grudnia 2019 roku, I CSK 271/19, Legalis nr 2277350; wyrok Sądu Najwyższego z dnia 16 czerwca 2016 roku, V CSK 625/15, OSNC 2017 $\mathrm{Nr} 4$, poz. 45. Odmiennie T. Justyński, Wysokość zachowku a problem nadużycia prawa - art. 5 k.c. Glosa do wyroku SN z dnia 7 kwietnia 2004 r., IV CK 215/03, „Państwo i Prawo” 2005, nr 6, s. 111 n.; wyrok Sądu Apelacyjnego w Szczecinie z dnia 21 maja 2013 roku, I ACa 101/13, Legalis nr 744951, w którym Sąd ten uznał, że okoliczności występujące na linii uprawniony do zachowku a zobowiązany do jego zapłaty, choć nie są pozbawione znaczenia, to nie mogą samodzielnie stanowić podstawy do stwierdzenia nadużycia prawa.

19 Postanowienie Sądu Najwyższego z dnia 19 grudnia 2019 roku, I CSK 271/19, Legalis nr 2277350.

20 P. Księżak, [w:] Kodeks cywilny. Komentarz, red. K. Osajda, Warszawa 2020, komentarz do art. 991 k.c., pkt 50; J. Kuźmicka-Sulikowska, [w:] Kodeks cywilny. Komentarz, red. E. Gniewek, P. Machnikowski, Warszawa 2019, komentarz do art. 991 k.c., pkt 7. Zob. również uchwałę z dnia 19 maja 1981 roku, III CZP 18/81, OSNCP 1981 nr 12, poz. 228, w której Sąd Najwyższy wskazał przykład, gdy głównym składnikiem spadku jest lokal zaspokający niezbędne potrzeby mieszkaniowe przy jednoczesnym braku innych składników spadku wystarczających na zapłatę zachowku w pełnej wysokości.

21 Wyrok Sądu Apelacyjnego w Warszawie z dnia 9 maja 2018 roku, V ACa 921/17, Legalis nr 1785962; A. Doliwa, [w:] Kodeks cywilny. Komentarz, red. M. Załucki, Warszawa 2020, komentarz do art. 991 k.c., nb 8.

22 M. Załucki, [w:] Kodeks cywilny. Komentarz, t. 6. Spadki (art. 922-1087), red. M. Fras, M. Habdas, Warszawa 2019, komentarz do art. 991 k.c., pkt 22. 
dowiedzeniu się o jego rażącym nagannym zachowaniu, polegającym na przykład na długoletnim znęcaniu się fizycznym lub psychicznym nad osobą najbliższą spadkodawcy (art. 1008 pkt 2 k.c.). Ponadto spadkodawca mógł nie wiedzieć, że uprawniony do zachowku był sprawcą przestępstwa uzasadniającego jego wydziedziczenie albo też wykrycie sprawcy nastąpiło po śmierci spadkodawcy po upływie trzech lat od otwarcia spadku, co uniemożliwiło uznanie go za niegodnego dziedziczenia (art. 929 k.c.) $)^{23}$. We wskazanych wyżej przypadkach nie sposób uznać, że stosowanie art. 5 k.c. do roszczeń o zachowek narusza naczelną zasadę prawa spadkowego, którą jest zasada swobody testowania. Natomiast w przypadku, gdy nie ma przeszkód natury prawnej lub faktycznej do wydziedziczenia, i pomimo istnienia ku temu podstaw, spadkodawca tego nie dokonał, należy uszanować wolę testatora co do niewywodzenia konsekwencji prawnych z nagannego zachowania uprawnionego do zachowku.

Zgodzić się jednakże należy z argumentacją Sądu Najwyższego zawartą w glosowanym wyroku w zakresie wymagalności roszczenia o zachowek. Sąd ten słusznie wskazał, że stan opóźnienia w spełnieniu świadczenia z tytułu zachowku należy oceniać indywidualnie w okolicznościach konkretnej sprawy. O stanie opóźnienia można mówić zaś wtedy, gdy zobowiązany zna wszystkie obiektywnie istniejące okoliczności pozwalające na ocenę zasadności i wysokości roszczenia $\mathrm{z}$ tytułu zachowku ${ }^{24}$. Obowiązek zapłaty na rzecz uprawnionego do zachowku ma charakter zobowiązania bezterminowego, do którego zastosowanie ma art. 455 k.c., zgodnie z którym termin spełnienia świadczenia nie jest oznaczony, ani nie wynika $z$ właściwości zobowiązania, świadczenie powinno być spełnione niezwłocznie po wezwaniu dłużnika do jego wykonania. Przepisy dotyczące roszczenia o zachowek, jak również właściwość zobowiązania, nie pozwalają zaś z góry na ustalenie terminu wymagalności tego roszczenia ${ }^{25}$. Roszczenie o zachowek staje się zatem wymagalne wraz z wezwaniem dłużnika do spełnienia świadczenia pod warunkiem ustalenia składników majątku spadkowego stanowiącego podstawę ustalenia wysokości zachowku ${ }^{26}$.

23 J. Kuźmicka-Sulikowska, Kodeks cywilny. Komentarz, red. E. Gniewek, P. Machnikowski, Warszawa 2019, komentarz do art. 991 k.c., pkt 7.

24 Por. między innymi wyrok Sądu Najwyższego z dnia 7 lutego 2013 roku, II CSK 403/12, Legalis nr 719210; wyrok Sądu Najwyższego z dnia 24 lutego 2016 roku, I CSK 67/15, Legalis nr 1461050; wyrok Sądu Najwyższego z dnia 22 czerwca 2016 roku, II CSK 279/16, Legalis nr 1716252 .

25 Wyrok Sądu Najwyższego z dnia 24 lutego 2016 roku, I CSK 67/15, Legalis nr 1461050; wyrok Sądu Najwyższego z dnia 30 czerwca 2011 roku, III CSK 282/10, Legalis nr 442129; W. Popiołek, [w:] Kodeks cywilny, t. 2. Komentarz do art. 450-1088. Przepisy wprowadzajace, red. K. Pietrzykowski, Warszawa 2021, komentarz do art. 445 k.c., pkt 5, 6.

26 Wyrok Sądu Najwyższego z dnia 17 września 2010 roku, II CSK 178/10, Legalis nr 250790; wyrok Sądu Najwyższego z dnia 6 marca 2014 roku, V CSK 209/13, Legalis nr 994641; wyrok Sądu Najwyższego z dnia 25 lutego 2016 roku, I CSK 67/15, Legalis nr 1461050; a także wyrok Sądu Apelacyjnego z dnia 22 października 2014 roku, I ACa 376/14, Legalis nr 1978565; wyrok Sądu Apelacyjnego w Białymstoku z dnia 13 maja 2016 roku, I ACa 53/16, Legalis nr 1472331. 
Reasumując, należy dopuścić zarówno możliwość miarkowania wysokości zachowku, jak również całościowego pozbawienia uprawnionego prawa do zachowku w sytuacji zaktualizowania się przesłanek nadużycia prawa podmiotowego na podstawie art. 5 k.c. W każdym jednak przypadku zastosowanie tego przepisu winno uwzględniać całokształt okoliczności, zarówno tych odnoszących się do osoby spadkodawcy, zobowiązanego, jak i uprawnionego do zachowku, przy uwzględnieniu powszechnie akceptowanych w społeczeństwie norm i ocen moralnych. Dopiero negatywna ocena roszczenia uprawnionego daje możliwość w pierwszej kolejności częściowego uwzględnienia powództwa, zaś w sytuacji stwierdzenia rażącego naruszenia zasad współżycia społecznego, Sąd powinien mieć możliwość oddalenia powództwa o zachowek na podstawie art. 5 k.c.

\title{
THE CHARGE OF ABUSE OF A SUBJECTIVE RIGHT AND DEPRIVATION OF THE RIGHT TO A RESERVED PORTION. A GLOSS TO THE JUDGMENT OF THE SUPREME COURT OF 28 MARCH 2018, V CSK 428/17
}

\begin{abstract}
Summary
The glossed judgment concerns the extremely important issue of the admissibility of applying Art. 5 of the Polish Civil Code to claims for a reserved share, both in terms of measuring its amount, as well as depriving the entitled part of the reserved portion. Although the very decision of the Supreme Court against the background of the facts of the case deserves approval, the thesis of the judgment, according to which it is not permissible to dismiss the claim for a reserved share under Art. 5 of the Polish Civil Code
\end{abstract}

Keywords: abuse of subjective right, reserved share, disinheritance

\section{BIBLIOGRAFIA}

Doliwa A., [w:] Kodeks cywilny. Komentarz, red. M. Załucki, Warszawa 2020.

Justyński T., Wysokość zachowku a problem nadużycia prawa - art. 5 k.c. Glosa do wyroku SN $z$ dnia 7 kwietnia 2004 r., IV CK 215/03, „Państwo i Prawo” 2005, nr 6.

Królikowski M., Mechanizm sądowego miarkowania wysokości zachowku jako przejaw dynamicznej wyktadni prawa cywilnego, „Przegląd Prawa i Administracji” 120, 2020, cz. 1.

Księżak P., [w:] Kodeks cywilny. Komentarz, red. K. Osajda, Warszawa 2020.

Kuźmicka-Sulikowska K., [w:] Kodeks cywilny. Komentarz, red. E. Gniewek, P. Machnikowski, Warszawa 2019.

Kwak A., Rodzina na wiele wariantów, ale czy z mniejszym zakresem solidarności?, „Studia Socjologiczne" 2017, nr 2.

Skowrońska-Bocian E., Wierciński J., [w:] Kodeks cywilny. Komentarz, t. 6. Spadki, red. J. Gudowski, Warszawa 2017. 
Sokołowski T., [w:] Kodeks cywilny, t. 3. Komentarz do art. 627-1088, red. M. Gutowski, Warszawa 2019.

Wilejczyk M., Zagadnienia etyczne części ogólnej prawa cywilnego, Warszawa 2014.

Wójcik S., Zoll F., [w:] System Prawa Prywatnego. Prawo spadkowe, t. 10, Warszawa 2015.

Załucki M., [w:] Kodeks cywilny. Komentarz, t. 6. Spadki (art. 922-1087), red. M. Fras, M. Habdas, Warszawa 2019.

Ziembiński Z., Wstęp do aksjologii dla prawników, Warszawa 1980. 